\title{
Kinetic Study on Dodecylbenzene Sulfonation in a Mixed Batch Reactor
}

\author{
Jamal M. Amous \\ Chemical Engineering Department, College of Engineering, University of Hail, Saudi Arabia
}

Copyright $\bigcirc 2016$ by authors, all rights reserved. Authors agree that this article remains permanently open access under the terms of the Creative Commons Attribution License 4.0 International License

\begin{abstract}
A mixed batch autoclave reactor was used to investigate the sulfonation reaction kinetics of pure samples of DodecylBenzene (DB). The effect of temperature in the range between 20 and $50{ }^{\circ} \mathrm{C}$, and the effect of the concentrations of Sulfur Trioxde and DodecylBenzene upon the sulfonation reaction rate were studied. Two sets of experiments were performed .The first is applying high $\mathrm{SO}_{3} / \mathrm{DB}$ molar ratio $\mathrm{C}_{\mathrm{SO} 3} / \mathrm{C}_{\mathrm{DB}}>>1$, the second is with high $\mathrm{DB} / \mathrm{SO}_{3}$ molar ratio $\left(\mathrm{C}_{\mathrm{DB}} / \mathrm{C}_{\mathrm{SO} 3}>>1\right)$. It was shown that the sulfonation reaction is a 0.74 order with respect to $\mathrm{DB}$ and a 1.59 order with respect to $\mathrm{SO}_{3}$. The reaction rate constant $\mathrm{k}$ was determined for both sets. The values determined for the frequency factor and activation energy were as per the following equation: $k=2.2172 \times 10^{3} \exp \left\{-5207 / R_{g} T\right\}$ (1). The kinetic model for the sulfonation reaction is $\mathrm{R}_{\mathrm{D} . \mathrm{B}}=$ $\mathrm{k}^{*} C_{S O 3}^{1.59 *} C_{D . B}^{0.74} "(2)$. The progress of the reaction was determined from $\mathrm{SO}_{3}$ concentration vs. time data conducted at different time intervals. Evaluations of $\mathrm{SO}_{3}, \mathrm{DB}$ concentrations and reaction rates were based on titrations of the inorganic phase with caustic soda standard solutions.
\end{abstract}

Keywords Sulfonation, Dodecylbenzene, Kinetics, Sulfonic Acid, Homogeneity, Detergents

\section{Introduction}

The recent developments in detergents industry reflect the worldwide trend in detergent products and quality.

The challenge of the recent decades for detergents industry is to produce cleaning products which are of essential role in our daily lives, which can safely and effectively remove soils, germs and other contaminants, help us to stay healthy, care for our homes and possessions, and make our surroundings more pleasant $[1,2]$.

Dodecylbenzene sulfonate's biodegradability and its high cleaning capability were the reasons for the producers went toward the production of large amounts of this detergent and to focus their attention on the chemical process techniques of the sulfonation of the DB [3].
Recent studies had led to the conclusion that the monomer $\mathrm{SO}_{3}$ is the true active ingredient in Oleum while $\mathrm{H}_{2} \mathrm{O}$ is acting as solvent. The $\mathrm{SO}_{3}$ Hydrates present at low temperatures are the monohydrates $\left(\mathrm{SO}_{3} . \mathrm{H}_{2} \mathrm{O}\right.$ or $100 \%$ $\left.\mathrm{H}_{2} \mathrm{SO}_{4}\right)$ and the dihydrates $\left(\mathrm{SO}_{3} .2 \mathrm{H}_{2} \mathrm{O}\right.$ or $\left.84.5 \% \mathrm{H}_{2} \mathrm{SO}_{4}\right)$ and the pyrosulfuric acid $\left(2 \mathrm{SO}_{3} \cdot \mathrm{H}_{2} \mathrm{O}\right.$ or $44.5 \%$ Oleum $[4,5,6]$.

In USA, 51 out of 101 working sulfonation plants apply Oleum, 44 of them apply $\mathrm{SO}_{3}$ while 5 units apply chlorosulfonic acid and one plant applies sulfoxidation [2].

Basic Chemistry supports that Sulfur trioxide $\left(\mathrm{SO}_{3}\right)$ reacts with the Dodecylbenzene to form a sulfur-carbon bond. One of the characteristics of this process is that the resultant Dodecylebenzene sulfonic acid is a stable molecule $[3,4,5,6,7]$ as per the following equation

$$
\mathrm{SO}_{3}+\mathrm{C}_{12} \mathrm{H}_{25} \mathrm{C}_{6} \mathrm{H}_{5} \rightarrow \mathrm{C}_{12} \mathrm{H}_{25} \mathrm{C}_{6} \mathrm{H}_{4} \mathrm{SO}_{3} \mathrm{H}
$$

Studies on the sulfonation of organic compounds were carried by Dresel and Hinshelwood (1944) [8], Stubbs, Williams and Hinshelwood (1948) [9] and more recently by Torres et al.(2008) [10]. Torres accepted a second order model for the reaction rate, first order with respect to both methyl esters and sulfur trioxide, while Dresel and Hinshelwood (1944), Stubbs, Williams and Hinshelwood (1948), performed kinetic studies on different Alkylbenzenes with $\mathrm{SO}_{3}$ and concluded that the reaction rate constant of this sulfonation reaction depends on the Arylbezene being sulfonated with values ranging between 48.8 to $7.85 \times 10^{-6}$ [liters/gmole.sec] and the activation energy is in the range of [4320 - 11400] cal/gmole.

Ratcliff (1954) [11], studied the sulfonation of benzene with $\mathrm{SO}_{3}$ and concluded that the reaction is 0.57 order with respect to Benzene and 1.24 with respect to $\mathrm{SO}_{3}$.

The primary aim of this study is to investigate the sulfonation of Dodecylbenzene with Oleum $22 \mathrm{wt} \%$.

The sulfonation is carried out in a well-mixed autoclave reactor ensuring homogeneity.

The kinetic study reported in this investigation was carried out in a stainless steel 316 alloy cylindrical autoclave (Figure. 1) equipped with a stirrer for agitation (80 R.P.M) with a total volume of $4868 \mathrm{~cm}^{3}$, having an internal diameter $\mathrm{D}_{\mathrm{i}}$, of $135 \mathrm{~mm}$ and a height $\mathrm{H}$ of $340 \mathrm{~mm}$. The height of the 
hemispherical head $\left(d_{x}\right)$ is $33.75 \mathrm{~mm}\left(d_{x}=0.25 D_{i}\right)$, the diameter of the agitating blade $\mathrm{dt}$ is $40.5 \mathrm{~mm}$, the distance between agitator and bottom of the reactor ht is $67.5 \mathrm{~mm}$, the width of the blades $\mathrm{w}$ is $10 \mathrm{~mm}$ and the width of the baffles wb is equal to $13 \mathrm{~mm}$.

\section{Raw Materials}

Dodecylbenzene is an Organic compound, colorless waxy solid consists of a Dodecyl group $\left(\mathrm{C}_{12} \mathrm{H}_{25}\right)$ attached to a Phenyl group $\left(\mathrm{C}_{6} \mathrm{H}_{5}\right)$. Dodecylbenzene is a precursor for Sodium dodecylbenzenesulfonate[12 ].

Sulfur trioxide is a clear oily colorless liquid. It may contain a haze and be off-white to light brown in appearance. Oleum is normally turbid and off-white in appearance [13].

The strength of Oleum used is $22 \mathrm{wt} \%\left(1.3458 \mathrm{SO}_{3} \cdot 1 \mathrm{H}_{2} \mathrm{O}\right)$. $\mathrm{SO}_{3}$ molar mass is equal to 80 and density at $30^{\circ} \mathrm{C}(\rho)=$ $1.890 \mathrm{gr} / \mathrm{cm}^{3}$.

Some of the properties of Dodecylbenze are given below:

$\begin{array}{lll}\text { - } & \text { Chemical formula } & \mathrm{C}_{18} \mathrm{H}_{30} \cdot \\ \text { - } & \text { Molar Mass } & 246.43 \mathrm{~g} / \text { mole. } \\ \text { - } & \text { Appearance } & \text { colorless liquid. } \\ \text { - } & \text { Melting point } & 0.857 \mathrm{~g} / \mathrm{cm}^{3} . \\ \text { - } & -7^{\circ} \mathrm{C} . \\ \text { - } & \text { Boiling point } & 290 \text { to } 410^{\circ} \mathrm{C} \\ \end{array}$

The properties of Oleum with different strengths are shown in Table 1.

Table 1. Properties of Oleum with different strengths

\begin{tabular}{|c|c|c|c|c|}
\hline Properties & $\mathrm{SO}_{3}$ & $65 \%$ Oleum & $\begin{array}{c}30 \% \\
\text { Oleu. }\end{array}$ & $\begin{array}{c}20 \% \\
\text { Oleu. }\end{array}$ \\
\hline Melting point $\left({ }^{\circ} \mathrm{C}\right)$ & 17 & 2 & 19 & -10 \\
\hline $\begin{array}{c}\text { Boiling point } \\
\left({ }^{\circ} \mathrm{C}\right)\end{array}$ & 45 & 58 & 121 & 142 \\
\hline $\begin{array}{c}\text { Density } \\
\text { at }\left(\mathrm{g} / \mathrm{cm}^{3}\right) 30^{\circ} \mathrm{C}\end{array}$ & 1.88 & 1.975 & 1.92 & 1.88 \\
\hline
\end{tabular}

\section{Experimental}

The first set of experiments was performed applying high $\left(\mathrm{CSO}_{3} / \mathrm{CDB}\right)$ molar ratio. $1666 \mathrm{~cm}^{3}$ of Oleum $22 \%$ and 1000 $\mathrm{cm}^{3}$ of Dodecylbenzene were loaded to the reactor, see Figure 1. These amounts contain 33.7439 gmoles of $\mathrm{SO}_{3}\left(\mathrm{~N}_{\mathrm{SO} 3}\right)$ and 3.484 gmoles of DB. All experiments of the first set were initiated with $\mathrm{C}\left({ }_{\mathrm{SO} 3}\right)=33.7439 / 2666=1.2657 \mathrm{X}$ $10^{-2}$ gmole $/ \mathrm{cm}^{3}$ while $\mathrm{C}(\mathrm{DB}) \quad=3.484 / 2666=$ $1.3068 \times 10^{-3}$ gmole $/ \mathrm{cm}^{3}$, thus $\mathrm{C}\left({ }_{\mathrm{SO} 3}\right) / \mathrm{C}(\mathrm{DB})=9.6854 \gg 1$.

Dodecylbenzene concentration changes were determined at different times. Samples of the reacting mixture of approximately $4 \mathrm{~cm}^{3}$ were picked at different time intervals, washed with $10 \mathrm{~cm}^{3}$ of distilled water and then left for approximately 6 hours for the separation of the organic phase in a burette.
The $\mathrm{H}_{2} \mathrm{SO}_{4}$ solution is then titrated with $1 \mathrm{M} \mathrm{NaOH}$ solutions. The amount of soda solution needed to neutralize sulfuric acid is used to evaluate the amount of $\mathrm{H}_{2} \mathrm{SO}_{4}$ and hence the $\mathrm{SO}_{3}$ present in the solution and thus the moles of D.B not reacted.

The proposed kinetic model for the sulfonation reaction rate is:

$$
-\mathrm{R}_{\mathrm{DB}}=\mathrm{k}\left(\mathrm{C}_{\mathrm{DB}}\right)^{\alpha 1} \cdot\left(\mathrm{C}_{\mathrm{SO} 3}\right)^{\alpha 2}
$$

Where $\mathrm{C}_{\mathrm{DB}}$ and $\mathrm{C}_{\mathrm{SO} 3}$ are the concentrations of $\mathrm{DB}$ and $\mathrm{SO}_{3}$. $\alpha_{1}$ and $\alpha_{2}$ are the reaction orders with respect to $\mathrm{SO}_{3}$ and $\mathrm{DB}$ respectively.

Since $\mathrm{SO}_{3}$ is in excess, its concentration is assumed constant (not altered throughout the experiment) and is considered to be equal to:

$$
\left(\mathrm{C}_{\mathrm{SO} 3}\right)_{\mathrm{ave}}=\left\{\mathrm{C}\left(\mathrm{SO}_{3}\right)_{\circ}+\mathrm{C}\left(\mathrm{sO}_{3}\right)_{\mathrm{f}}\right\} / 2 .
$$

The number of $\mathrm{SO}_{3}$ moles not reacted are calculated as per the following equation:

$$
\begin{aligned}
& \mathrm{N}(\mathrm{sO}) \mathrm{i}=\left[\mathrm{Vi}_{\mathrm{NaOH}} * 1.0 *\left\{2666-\sum_{i=1}^{i=n}(\mathrm{vsi})\right\}\right] /(\mathrm{vsi} * \\
& \text { 1000), }
\end{aligned}
$$

where $\mathrm{V} i_{(\mathrm{NaOH})}$ is the volume of $1.0 \mathrm{M}$ caustic soda solution needed to neutralize $\mathrm{v}_{\mathrm{si}} \mathrm{cm}^{3}, 1.0$ is the molarity of the caustic soda solution, $\mathrm{V}_{\mathrm{si}}$ is the volume in $\mathrm{cm}^{3}$ of the sample picked in the $i^{\text {th }}$ sampling, $n$ is the total number of samples . The number of unreacted DB moles is calculated as follows:

$$
\left(\mathrm{N}_{\text {D.B }}\right)_{\mathrm{i}}=\left(\mathrm{N}_{\text {D.B }}\right)_{\circ}-\Delta_{(\mathrm{NSO}) \mathrm{i}} \text {. }
$$

where $\Delta\left(\mathrm{N}_{\mathrm{SO} 3}\right) \mathrm{i}=\mathrm{N}\left(\mathrm{SO}_{3}\right)_{\circ}-\mathrm{N}\left(\mathrm{SO}_{3}\right)_{\mathrm{i}}$

The D.B concentrations are estimated by dividing the number of un reacted moles by the remaining volume which is equal to $\left(2666-\Sigma \mathrm{v}_{s i}\right) \mathrm{cm}^{3}$.

Four classes of experiments were conducted, the first was at 20 , the second at $30^{\circ} \mathrm{C}$, the third at $40^{\circ} \mathrm{C}$ while the forth was at $50{ }^{\circ} \mathrm{C}$, for each class we estimated the observed reaction rate constant $\mathrm{k}_{\mathrm{Ti}}^{\prime}$ which is equal to the intrinsic reaction rate constant $\mathrm{k}$ multiplied by the average concentration of sulfur trioxide $\left(\mathrm{C}_{\mathrm{SO}}\right)_{\text {ave }}$ raised to the power $\alpha_{2}$ which is equal to $\left[\left(\mathrm{C}_{\mathrm{SO} 3}\right)_{\mathrm{ave}}\right]^{\mathrm{a} 2}$.

In the second set of experiments, we performed classes with excess in $\mathrm{DB}$ moles against $\mathrm{SO}_{3}$.

We used $3000 \mathrm{~cm}^{3}$ of DB with $95 \mathrm{~cm}^{3}$ of Oleum $22 \%$ in the first three classes and $3000 \mathrm{~cm}^{3}$ of DB with $65 \mathrm{~cm}^{3}$ oleum $22 \%$ in the fourth class of experiments. In this second set, we initiated our experiments with 10.4512 gmoles of DB against 1.926 moles of $\mathrm{SO}_{3}$ in the first three classes and 1.295 gmole $\mathrm{SO}_{3}$ in the fourth class of the second set against 10.4512 gmoles of DB.

Experimental runs were performed at $20,30,40$, and $50^{\circ} \mathrm{C}$. Experimental data was treated and values of the observed rate constant $\mathrm{k}^{\prime \prime} \mathrm{Ti}$ were deduced, Where $\mathrm{k}$ ' $\mathrm{Tj}$ is equal to $\mathrm{k}$ multiplied by $\left(\mathrm{C}_{\mathrm{DB}}\right)_{\mathrm{ave}}$. raised to the power $\alpha 1$ which is equal to $\left[\left(\mathrm{C}_{\mathrm{DB}}\right)_{\mathrm{ave}}\right]^{\mathrm{a} 1}$. 


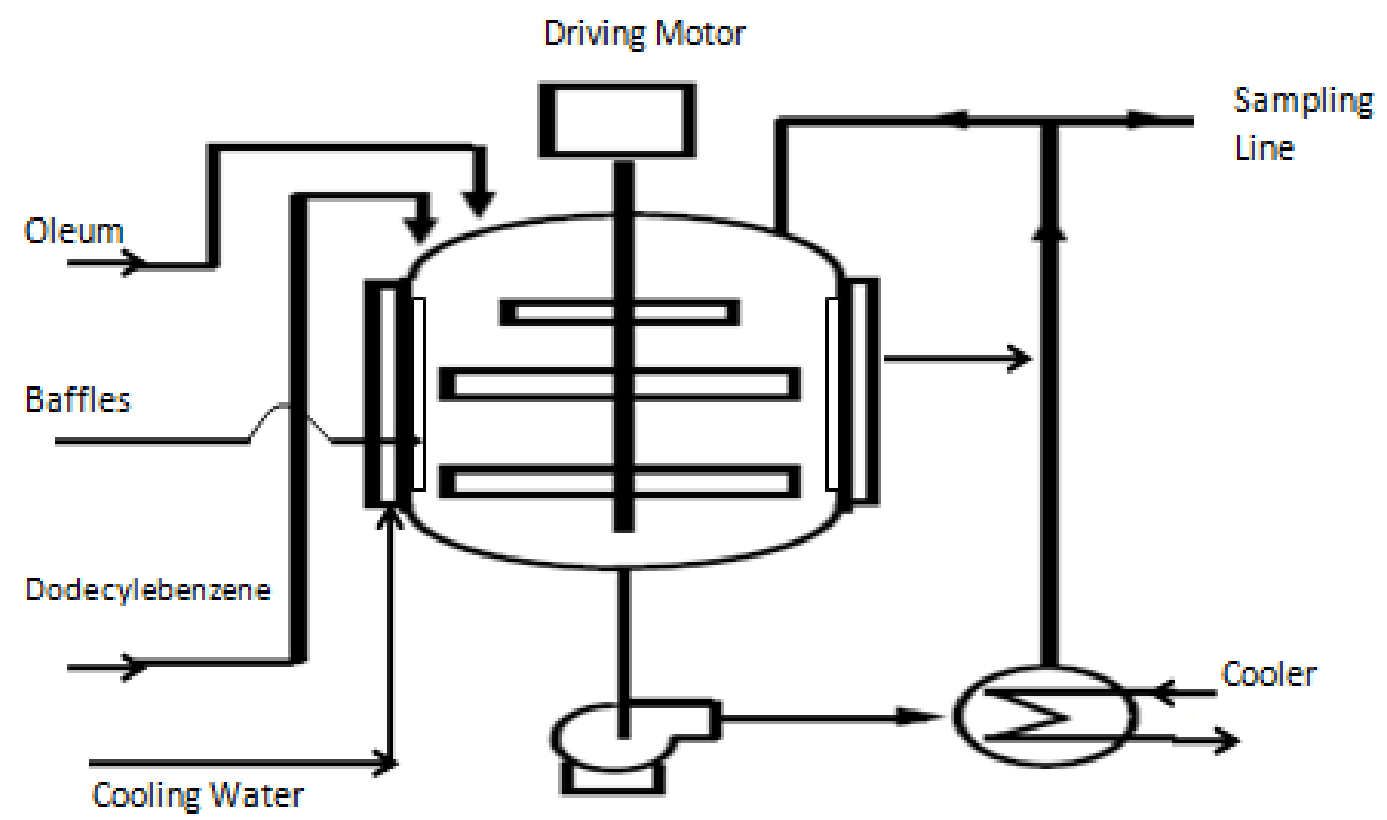

Recycling Pump

Figure 1. Sulfonation Reactor

Table 1. Typical Experimental Data Sheet Showing the Measured and Calculated Variables in Each Experiment

\begin{tabular}{|c|c|c|c|c|c|c|c|c|c|}
\hline $\mathrm{i}$ & $\begin{array}{l}\text { Time } \\
\text { [sec.] }\end{array}$ & $\begin{array}{c}\mathrm{v}_{\mathrm{s}} \\
\mathrm{cm}^{3}\end{array}$ & $\begin{array}{l}\mathrm{V}_{\mathrm{NaOH}} \\
\mathrm{cm}^{3}\end{array}$ & $\begin{array}{c}\mathrm{N}_{\mathrm{SO} 3} \\
\text { gmoles }\end{array}$ & $\begin{array}{c}\mathrm{N}_{\text {D. }} \\
\text { gmoles }\end{array}$ & $\begin{array}{l}\text { C (D.B) } \\
\text { gmole/lt. }\end{array}$ & $\begin{array}{c}-\left\{\Delta \mathrm{C}_{\mathrm{D} . \mathrm{B}} / \Delta \mathrm{t}\right\} \\
\mathrm{X} 10^{3}\end{array}$ & $\begin{array}{l}\left(\mathrm{C}_{\mathrm{D} . \mathrm{B}}\right)_{\mathrm{ave}} \\
\text { gmole/lt. }\end{array}$ & $\begin{array}{l}V_{\mathrm{r} . \mathrm{m}} \\
\mathrm{cm}^{3}\end{array}$ \\
\hline 1 & 0 & 3.5 & 44.3 & 33.7439 & 3.484 & 1.30683 & 0.715944 & 1.14222 & 2666 \\
\hline 2 & 460 & 3.5 & 43.2 & 32.8629 & 2.6029 & 0.97762 & 0.558389 & 0.812984 & 2662.5 \\
\hline 3 & 1050 & 3.5 & 42.1 & 31.9840 & 1.7240 & 0.6484 & 0.462020 & 0.597997 & 2659 \\
\hline 4 & 1267 & 3.5 & 41.8 & 31.7143 & 1.4543 & 0.5476 & 0.341990 & 0.397264 & 2655.5 \\
\hline 5 & 2300 & 3.5 & 40.8 & 30.9174 & 0.655 & 0.2469 & 0.152762 & 0.16792 & 2652 \\
\hline 6 & 3171 & 3.5 & 40.3 & 30.4956 & 0.2356 & 0.0889 & 0.082910 & 0.052819 & 2648.5 \\
\hline 7 & 4042 & 3.5 & 40.1 & 30.3041 & 0.0441 & 0.01669 & & & 2645 \\
\hline
\end{tabular}

\section{Batch Sulfonator}

A schematic presentation of the sulfonation process is shown in Figure 1. The desired amounts of Oleum and DB are loaded to the sulfonation reactor which is equipped with an agitating system and jacketed for evolved heat removal. The reacting mixture is withdrawn from the reactor through an opening in the bottom with the aid of a pump and returned to the top of the reactor after being cooled properly in the cooler. Sampling is done from the recycling line optionally at different time intervals.

\section{Results and Discussion}

Illustration of the Experimental data obtained, is shown in Table 1 . The operating conditions are as follows: $T_{I}=20\left({ }^{\circ} \mathrm{C}\right)$, the pressure is $\mathrm{P}=1.1$ atma, the rotational speed of the agitator $\mathrm{RPM}=80$, and the initial total volume is $\mathrm{V}_{\mathrm{t}^{\circ}}=2666$ $\mathrm{cm}^{3}$

Similar treatments are carried for all other experiments for the temperatures applied, 30,40 and $50{ }^{\circ} \mathrm{C}$.

The number of samples picked for each class(i) ranged between 7 and 9 , Where $\{\Delta \mathrm{CD} . \mathrm{B} / \Delta \mathrm{t}\} \times 10^{3}$ is the rate of consumption of DB in [gmoles DB $/$ lt. sec. $]^{*} 10^{3}$

The slope ( $\alpha \mathrm{i})$ and the intercept (lnk'Ti) of the line:

$$
\ln (-\mathrm{RDB})=\ln \mathrm{k}^{\prime} \mathrm{Ti}+\alpha \ln \left(\mathrm{C}_{\mathrm{DB}}\right) \text {. }
$$

were obtained.

The slope is equal to the order of reaction ( $\alpha 1)$ with respect to DB. The intercept is equal to $\operatorname{lnk} \mathrm{K}^{\prime} \mathrm{Ti}$, wherek'Ti is the observed reaction rate constant $=\mathrm{kTi}^{*}\left[\left(\mathrm{CSO}_{3}\right)_{\mathrm{ave}}\right] \mathrm{a} 2$, $\mathrm{kTi}$ is the intrinsic reaction rate constant.

The results of the first set of experiments are given in 
Table 2.

Thus the order of the reaction with respect to DB $(\alpha 1)$ is taken as the average value of all the obtained values of $\alpha 1$ for the four temperatures applied, i.e $\left(a_{1}\right)_{\text {ave }}=$ $(0.72+0.71+0.68+0.83) / 4=0.74$

This study showed that an increase in the temperature from 20 to $30{ }^{\circ} \mathrm{C}$ led to an increase in the reaction rate constant by 1.74 times and the increase in temperature from 30 to $40{ }^{\circ} \mathrm{C}$ increased the rate constant by 1.82 times while the increase in temperature from 40 to $50^{\circ} \mathrm{C}$ increased the rate constant by 1.31 .

In the second set, experiments conducted at $\mathrm{Tj}=20,30$ and $40^{\circ} \mathrm{C}$ with $\left(\mathrm{CDB} / \mathrm{CSO}_{3}\right)>>1.0$, were initiated with $3000 \mathrm{~cm}^{3}$ of DB and $179.55 \mathrm{gr}$. Oleum $22 \%\left(95 \mathrm{~cm}^{3}\right)$ fed to the reactor, thus ensuring that the initial number of $\mathrm{DB}$ moles( $\mathrm{N} \mathrm{DB})^{\circ}$ are 10.451 gmoles and those for $\mathrm{SO}_{3}$ are $\left(\mathrm{NSO}_{3}\right)=1.923$ gmoles. At $50{ }^{\circ} \mathrm{C}$ the run was initiated with 122.85 gr Oleum $22 \%\left(65 \mathrm{~cm}^{3}\right.$ Oleum $)$ and $3000 \mathrm{~cm}^{3}$ of DB. For titrating the picked samples we applied a $0.1 \mathrm{M} \mathrm{NaOH}$ solution. The results of the second set of experiments are given in Table 3 . $\alpha 2$ is the reaction order with respect to $\mathrm{SO}_{3}$ and the observed reaction rate constant

$$
\mathrm{k}_{\mathrm{Tj}}{ }^{\prime \prime}=\mathrm{k}_{\mathrm{Tj}} *\left[\left(\mathrm{C}_{\mathrm{DB}}\right)_{\mathrm{ave}}\right]^{\mathrm{a} 1} .
$$

Thus the average value of $\alpha 2=(\mathrm{a} 2)_{\text {ave }}=$ $(1.91+1.72+1.41+1.33) / 4=1.59$, which means that the sulfonation reaction is 1.59 order with respect to $\mathrm{SO}_{3}$.

From the above mentioned values of $\alpha 1, \alpha 2, \mathrm{k}_{\mathrm{Ti}}{ }^{\prime}$ and $\mathrm{k}_{\mathrm{Tj}}{ }^{\prime \prime}$, $\mathrm{k}_{\mathrm{Ti}}$ and $\mathrm{k}_{\mathrm{Tj}}$ are calculated by the following relations:

$\mathrm{k}_{\mathrm{Ti}}=\mathrm{k}_{\mathrm{Ti}}{ }^{\prime} /\left[\left(\mathrm{CSO}_{3}\right) \text { ave }\right]^{\mathrm{a} 2}$ “ “ (9)”, for $\mathrm{Ti}^{\prime}=20,30,40$ and $50^{\circ} \mathrm{C}$.

And $\mathrm{k}_{\mathrm{Tj}}=\mathrm{k}_{\mathrm{Tj}}{ }^{\prime \prime} /\left[(\mathrm{CDB})_{\mathrm{ave}}\right]^{\mathrm{a} 1}$. “(10)”, for $\mathrm{Tj} "=20,30,40$, $50{ }^{\circ} \mathrm{C}$.

Determined values of $\mathrm{k}_{\mathrm{Ti}}$ and $\mathrm{k}_{\mathrm{Tj}}$ are shown in Table 2 and Table 3.

Table 2. Results of the First Set of experiments.

\begin{tabular}{|c|c|c|c|c|}
\hline Temperature $\mathrm{Ti},\left({ }^{\circ} \mathrm{C}\right)$ & 20 & 30 & 40 & 50 \\
\hline $\begin{array}{c}\text { Average } \mathrm{SO}_{3} \text { concentration, } \\
\text { gmole/L }\end{array}$ & 12.0571 & 12.2875 & 12.0429 & 12.0857 \\
\hline$\alpha_{l}$ & 0.72 & 0.71 & 0.68 & 0.83 \\
\hline $\operatorname{lnk}^{\prime}$ & -7.3395 & -6.75296 & -6.18595 & -5.90286 \\
\hline$k_{T i}^{\prime}$ & $6.49375 \times 10^{-4}$ & $1.16742 \times 10^{-3}$ & $2.0581 \times 10^{-3}$ & $2.7316 \times 10^{-3}$ \\
\hline $\boldsymbol{k}_{T i}$ & $1.23971 \times 10^{-5}$ & $2.16262 \times 10^{-5}$ & $3.9364 \times 10^{-5}$ & $5.19523 \times 10^{-5}$ \\
\hline
\end{tabular}

Table 3. Results of the Second Set of Experiments

\begin{tabular}{|c|c|c|c|c|}
\hline Temperature $\mathrm{Tj}^{\circ} \mathrm{C}$ & 20 & 30 & 40 & 50 \\
\hline Average D.BConcentration, mole/lt & 3.2569 & 3.2145 & 3.0851 & 3.2107 \\
\hline$\alpha 2$ & 1.91 & 1,72 & 1.41 & 1.33 \\
\hline $\operatorname{lnk}^{\prime \prime}$ & -6.83 & -6.4521 & -5.8641 & -5.0541 \\
\hline $\mathrm{kTj}^{\prime \prime}$ & $1.0809 \times 10^{-3}$ & $1.5772 \times 10^{-3}$ & $2.8396 \times 10^{-3}$ & $6.3831 \times 10^{-3}$ \\
\hline $\mathrm{kTj}$ & $1.6535 \times 10^{-4}$ & $2.4636 \times 10^{-4}$ & $4.7350 \times 10^{-4}$ & $9.9894 \times 10^{-4}$ \\
\hline
\end{tabular}

The overall intrinsic reaction rate constant $k$ at $20,30,40$ and $50\left({ }^{\circ} \mathrm{C}\right)$ is determined from the following relation :

$$
\mathrm{k}=\left\{\mathrm{k}_{\mathrm{Ti}} * \mathrm{k}_{\mathrm{Tj}}\right\}^{1 / 2} \text { “ }
$$

Values of $k$ evaluated for each temperature are shown in Table 4.

Table 4. Values Obtained for the Intrinsic Reaction Rate Constant $\mathrm{k}$.

\begin{tabular}{|c|c|c|c|c|}
\hline $\mathrm{T}$, & $20{ }^{\circ} \mathrm{C}$ & $30{ }^{\circ} \mathrm{C}$ & $40{ }^{\circ} \mathrm{C}$ & $50^{\circ} \mathrm{C}$ \\
\hline $\mathrm{k}_{\mathrm{T}}$ & $4.5275 \times 10^{-5}$ & $7.2992 \times 10^{-5}$ & $1.3652 \times 10^{-4}$ & $2.2781 \times 10^{-4}$ \\
\hline
\end{tabular}

The frequency factor and the activation energy of the specific reaction rate $k_{T}=k_{\circ} \cdot \exp \left(-E / R_{g} T\right)$, were determined by plotting $\ln k$ versus $(1 / T)$.

The graphical presentation of $\ln k$ versus $(1 / T)$ is shown in Figure 2. 


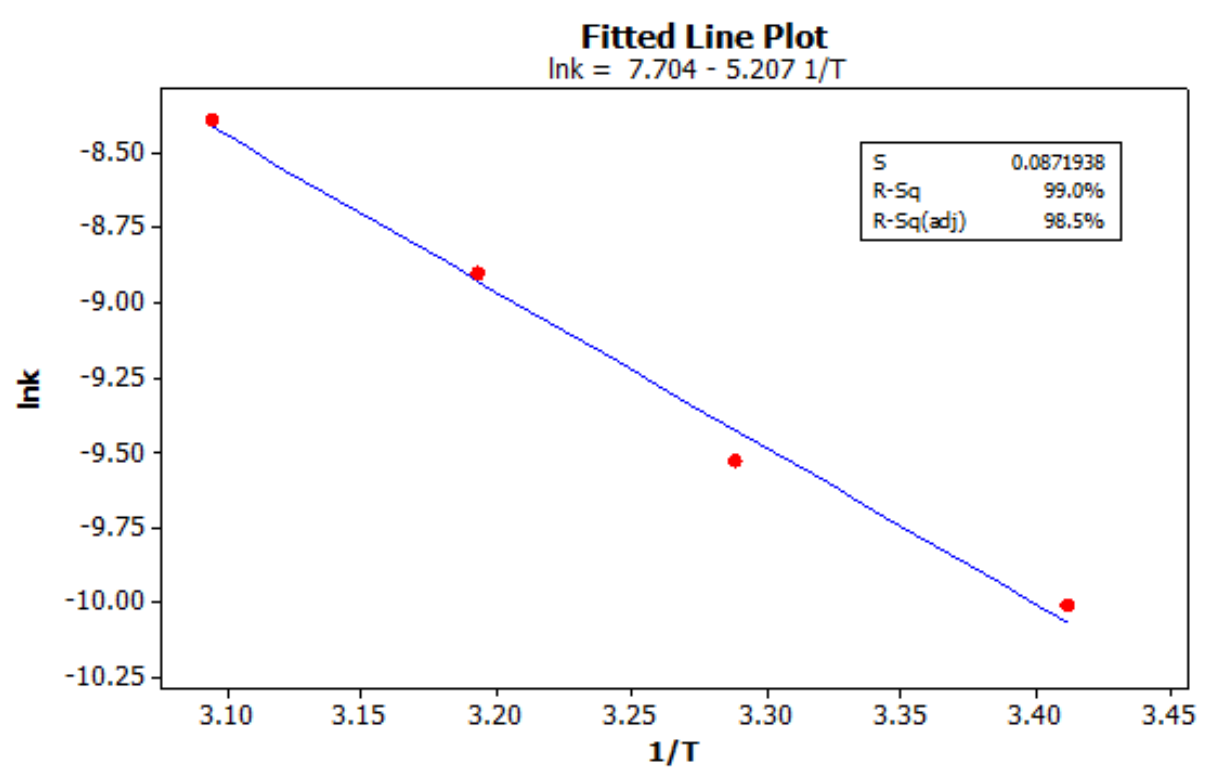

Figure 2. Graphical presentation of $\ln k$ versus $1 / T, T[K]$

Hence $\ln k_{\circ}=7.704, k_{\circ}=2.2172 \times 10^{3}$

The slope of the line is equal to -5207 and the activation energy $E=8.314 * 5207=43290.99 \mathrm{~J} / \mathrm{mole}, \quad(R=8.314$ J./mol.K).

\section{Conclusions}

The mixed batch reactor proved to be a successful research tool for the investigation of the technical kinetics of sulfunation systems, demonstrating a superior performance compared to other types of operating chemical reactors.

It ensures reasonable determinations of Dodecylbenzene sulfonation intrinsic kinetic parameters. Thus for sound intrinsic kinetic parameters evaluation, preference should be given to the mixed reactor.The results obtained in this study showed that reaction orders deduced with respect to both components support that sulfur trioxide is more active than D.B and that the temperature influence on the intrinsic rate constant depends on the range of temperature applied in this sulfonation reaction.

Oleum as a sulfonating agent and reaction technical kinetic parameters (temperature, $\mathrm{SO}_{3}$ and Dodecylbenzene concentrations) is well determined applying this type of reacting system, ensuring homogeneity in all reaction parameters all over the reaction space with the aid of the agitating operating system.

\section{Nomenclature}

1. $\alpha_{1}, \alpha_{2}$ : reaction orders with respect to $\mathrm{DB}$ and $\mathrm{SO}_{3}$ respectively.

2. $\mathrm{C}_{\mathrm{DB}}$ : concentration of $\mathrm{DB}$, gmoles /liter

3. $\mathrm{C}_{\mathrm{SO} 3}$ : concentration of $\mathrm{SO}_{3}$, gmoles /liter

4. $\mathrm{C}_{(\mathrm{i}) a v e}$ : average concentration of reagent (i), gmole/liter.
5. $\mathrm{k}:$ intrinsic reaction order

6. $\mathrm{k}^{\prime}: \mathrm{k}^{*}\left[\left(\mathrm{C}_{\mathrm{SO} 3}\right)_{\mathrm{ave}}\right]^{\mathrm{a} 2}$

7. $\mathrm{k}^{\prime \prime}: \mathrm{k}^{*}\left[\left(\mathrm{C}_{\mathrm{DB}}\right)_{\mathrm{ave}}\right]^{\mathrm{a} 1}$

8. $\mathrm{M}_{\mathrm{NaOH}}$ : molarity of $\mathrm{NaOH}$

9. $\mathrm{N}_{\mathrm{SO} 3}$ : number of $\mathrm{SO}_{3}$ gmoles

10. $\mathrm{N}_{\text {D.B }}$ : number of $\mathrm{DB}$ gmoles

11. $\mathrm{P}$ : the pressure in the reactor, atma

12. $\mathrm{R}$ :universal gas constant, $\mathrm{J} / \mathrm{mol} . \mathrm{K}$

13. $-\mathrm{R}_{\text {(D.B) }}$ : the rate of the sulfonation reaction, gmole/lt.s

14. RPM: revolutions per minute

15. Sec: seconds

16. T: temperature, $\mathrm{K}$

17. Vt: total volume, $\mathrm{cm}^{3}$

18. Vsi: volume of each sample, $\mathrm{cm}^{3}$.

19. $\Sigma\left[\mathrm{Vs}_{(\mathrm{i}-1)}\right], \mathrm{i}=1,2,3, \ldots, \mathrm{n}-1$ : the summation of the volumes of all samples including the (i-1) ${ }^{\text {th }}$ sample. $\mathrm{cm}^{3}$ 20. $\mathrm{V}_{\mathrm{NaOH}}$ : the volume of $\mathrm{NaOH}$ solution needed for titration, $\mathrm{cm}^{3}$.

21. $\mathrm{V}_{\mathrm{r} . \mathrm{m}}$ : the remaining volume of the reacting mixture after the $\mathrm{i}^{\text {th }}, \mathrm{cm}^{3}$

\section{Acknowledgements}

I thank Dr. Nader Mohamad Okasha for his help in proofreading this paper.

\section{REFERENCES}

[1] Y.P. Zhu, M.J. Rosen, S. W. Morral, J. Tolls, J. Surfactants Deterg., Vol. 1, No. 2, pp.187-193,1998,.

[2] R.J. Lewis, Sax's Dangerous Properties of Industrial Materials, 9th edition, Volumes 1-3, Van Nostrand Reinhold, New York, 1996. 
[3] W.H. De Groot, Sulphonation Technology in the Detergent Industry. Klwer Academic Publisher, ISBN 0-7923-1202-3, Dordrecht 1991.

[4] M.Schwartz and J.W. Perry, Surface Active Agents, Interscience Publishers Inc., New.York, 1949.

[5] N.C. Foster, Sulfonation and Sulfation Processes, (C) The Chemithon Corporation, 1997.

[6] E. M. Suter, A. W. Weston, Direct Sulfonation of Aromatic Hydrocarbons and their Halogen Derivatives, in "Organic Reactions" vol.3 , John Wiley \&Sons Inc., New York ,1946.

[7] E.E. Gilbert, Sulfonation of Aromatic hydrocarbons, in the Chemistry of Petroleum Hydrocarbons, Vol.3, Reinhold Publishing Corporation, New York, 1955.

[8] E. Dresel and C. N. Hinshelwood, The kinetics of the sulphonation of some aromatic compounds by sulphur trioxide, Journal of Chemical Society 1948, p- 649.

[9] F. J. Stubbs, C. D. Williams and C. N. Hinshelwood, The kinetics of aromatic sulphonation reactions. sulphonation by sulphuric acid in nitrobenzene solution, J. Chem. Soc., 1948, 1065 .

[10] J.A. Torres, P.C. Narvaez, O.Y. Suarez, F.J. Sanchez,). Sulfonation of methyl esters derived from palm oil, Corpica Cienc. Techol. Agropecu. 2008b, Vol.9, No. 2, pp.77- 87.

[11] G.A.Ratcliff, Kinetics of Sulphonation Reactions, Ph.D.Dissertaion, Cornell Univ, Ithaca, NY, 1954.

[12] K. Kosswig, Surfactants, Ullmann's Encyclopedia of Industrial Chemistry, Wiley-VCH, Weinheim, 2005.

[13] R. E. Kirk,D. F. Othmer, Sulfuric Acid and Sulfur Trioxide, Encyclopedia of Chemical Technology , 3rd ed., Vol. 22, John Wiley \& Son, New York, 1983. 